\begin{tabular}{|l|l|l||}
\hline \multicolumn{2}{|c|}{ PublisherInfo } \\
\hline \hline PublisherName & $:$ & BioMed Central \\
\hline \hline PublisherLocation & $:$ & London \\
\hline \hline PublisherImprintName & $:$ & BioMed Central \\
\hline \hline
\end{tabular}

\title{
Endotoxin in dust and bronchial asthma
}

\begin{tabular}{|l|l|l||}
\hline \multicolumn{2}{|c||}{ ArticleInfo } \\
\hline \hline ArticleID & $:$ & 1604 \\
\hline \hline ArticleDOI & $:$ & $10.1186 /$ rr-2001-68504 \\
\hline \hline ArticleCitationID & $:$ & 68504 \\
\hline \hline ArticleSequenceNumber & $:$ & 15 \\
\hline \hline ArticleCategory & $:$ & Paper Report \\
\hline \hline ArticleFirstPage & $:$ & 1 \\
\hline \hline ArticleLastPage & $:$ & 3 \\
\hline \hline & & RegistrationDate : 2001-9-14 \\
ArticleHistory & $:$ & Received \\
\hline \hline ArticleCopyright & $:$ & Biomed Central Ltd2001-4-26 \\
\hline \hline ArticleGrants & $:$ & \\
\hline \hline ArticleContext & $:$ & 129312211 \\
\hline \hline
\end{tabular}


Undurti Das, ${ }^{\text {Aff1 }}$

Corresponding Affiliation: Aff1

Aff1 EFA Sciences LLC, Norwood, MA, USA

\section{Keywords}

Asthma, endotoxin, Th2 responses

\section{Context}

It is known that endotoxin present in house dust can not only cause but also increase the severity of asthma in both children and adults. Childhood asthma has been significantly associated with dust-based endotoxin in two situations: when wheezing episodes continued through age 3 or 4 , and when wheezing began at age 3 or 4 . In this study, a possible association between exposure to house dust endotoxin within the first 3 months after birth and wheezing during the first year of life was investigated in children with a familial predisposition to asthma or allergy.

\section{Significant findings}

Elevated endotoxin exposure was associated with a significantly increased risk of repeated wheeze. Presence of a dog in the home was found to be strongly associated with measured endotoxin in family room dust. Based on these studies it was suggested that presence of a dog is an important contributor to increased endotoxin levels in house dust, and that elevated endotoxin levels in house dust may increase the risk of wheezing in the first year of life.

\section{Comments}

Atopic diseases, including asthma, are chronic disorders of increasing importance in economically developed countries. It is estimated that $10-20 \%$ of children have symptoms of asthma. Endotoxin in house dust is a significant risk factor in inducing and increasing the severity of asthma. Endotoxin is a proinflammatory agent that promotes Th2 responses and thus may play a role in asthma in general and in childhood asthma in particular. Although the present study showed that endotoxin in house dust 
contributes to wheezing during the first year of life, it is not known whether this leads to the development of asthma in later life.

\section{Methods}

Endotoxin measurement by kinetic Limulus assay

\section{Additional information}

\section{References}

1. Park J-H, Gold DR, Spiegelman DL, Burge HA, Milton DK: House dust endotoxin and wheeze in the first year of life. Am J Respir Crit Care Med . 2001, 163: 322-328. 